\title{
Expression of a Variant Form of the Glutamate Transporter GLT1 in Neuronal Cultures and in Neurons and Astrocytes in the Rat Brain
}

\author{
Weizhi Chen, ${ }^{1}$ Chiye Aoki, ${ }^{4}$ Veeravan Mahadomrongkul, ${ }^{4}$ Christian E. Gruber, ${ }^{5}$ Guang Jian Wang, ${ }^{1}$ \\ Rachel Blitzblau, ${ }^{1}$ Nina Irwin, ${ }^{2}$ and Paul A. Rosenberg ${ }^{1,3}$ \\ Departments of ${ }^{1}$ Neurology and ${ }^{2}$ Neurosurgery, Children's Hospital, and ${ }^{3}$ Program in Neuroscience, Harvard Medical \\ School, Boston, Massachusetts 02215, ${ }^{4}$ Center for Neural Science, New York University, New York, New York 10003, \\ and 5 Invitrogen, Frederick, Maryland 21704
}

To identify glutamate transporters expressed in forebrain neurons, we prepared a cDNA library from rat forebrain neuronal cultures, previously shown to transport glutamate with high affinity and capacity. Using this library, we cloned two forms, varying in the $\mathrm{C}$ terminus, of the glutamate transporter GLT1. This transporter was previously found to be localized exclusively in astrocytes in the normal mature brain. Specific antibodies against the $\mathrm{C}$-terminal peptides were used to show that forebrain neurons in culture express both GLT1a and GLT1b proteins. The pharmacological properties of glutamate transport mediated by GLT1a and GLT1b expressed in COS-7 cells and in neuronal cultures were indistinguishable. Both GLT1a and GLT1b were upregulated in astrocyte cultures by exposure to dibutyryl cAMP. We next investigated the expression of GLT1b in vivo. Northern blot analysis of forebrain RNA revealed

Glutamate transport is the major if not the only mechanism other than diffusion for clearing the excitatory transmitter glutamate from the extracellular space (Nicholls and Attwell, 1990; Lipton and Rosenberg, 1994; Rusakov and Kullmann, 1998; Danbolt, 2001). In addition to being the primary excitatory transmitter, glutamate is also paradoxically neurotoxic and has been implicated in important acute and chronic diseases of the nervous system (Meldrum and Garthwaite, 1990; Lipton and Rosenberg, 1994). Glutamate transport has been shown to be important in protecting neurons from the excitotoxicity of exogenous glutamate (Mangano and Schwarcz, 1983; Rosenberg and Aizenman, 1989; Rosenberg et al., 1992; Robinson et al., 1993) as well as endogenous glutamate (Rothstein et al., 1996; Tanaka et al., 1997; Wang et al., 1998b). Five glutamate transporters have been cloned to date (Kanai and Hediger, 1992; Pines et al., 1992; Storck et al.,

Received Nov. 28, 2001; revised Dec. 20, 2001; accepted Dec. 20, 2001.

This work was funded by a grant from the Ron Shapiro Charitable Foundation (P.A.R.); the Muscular Dystrophy Association (P.A.R.); an Office of Naval Research grant to Solicitation No. 99-019; National Institutes of Health Grants NS 40753 (P.A.R.), NS 41883 (P.A.R.), NS41091 (C.A.), and EY13145 (C.A.); a Mental Retardation Core Grant (HD18655); and National Eye Institute Core Grant EY13079. We are grateful to Dr. Kristen Harris for her critical evaluation of this manuscript and to Dr. Harris and Dr. Rachael Neve for encouragement and support throughout the course of this project. We are also grateful for the contribution of Dr. Ray Hadley in the library screening.

Correspondence should be addressed to Dr. Paul A. Rosenberg, Enders Research Building, Department of Neurology, Children's Hospital, 300 Longwood Avenue, Boston, MA 02215. E-mail: paul.rosenberg@tch.harvard.edu.

G. J. Wang's present address: Department of Pharmacology, University of Minnesota Medical School, Minneapolis, MN 55455.

R. Blitzblau's present address: Department of Neuroscience, Tufts University Medical School, Boston MA 02111.

Copyright (C) 2002 Society for Neuroscience $\quad 0270-6474 / 02 / 222142-11 \$ 15.00 / 0$ two transcripts of $\sim 3$ and $11 \mathrm{~kb}$ that became more plentiful with developmental age. Immunoblot analysis showed high levels of expression in the cortex, hippocampus, striatum, thalamus, and midbrain. Pre-embedding electron microscopic immunocytochemistry with silver-enhanced immunogold detection was used to localize GLT1b in vivo. In the rat somatosensory cortex, GLT1b was clearly expressed in neurons in presynaptic terminals and dendritic shafts, as well as in astrocytes. The presence of GLT1b in neurons may offer a partial explanation for the observed uptake of glutamate by presynaptic terminals, for the preservation of input specificity at excitatory synapses, and may play a role in the pathophysiology of excitotoxicity.

Key words: glutamate; transport; dihydrokainate; presynaptic; astrocytes; synapse; excitotoxicity

1992; Fairman et al., 1995; Arriza et al., 1997). The major transporter of the forebrain is GLT1, and in GLT1 knock-out mice, $<6 \%$ of glutamate transport activity remains in membrane preparations derived from cerebral cortex compared with wildtype animals (Tanaka et al., 1997).

In the mature brain, GLT1 protein has been found to be associated only with astrocytes (Rothstein et al., 1994; Lehre et al., 1995). A post-embedding immunogold study using an antibody directed against the whole GLT1 protein that reacts strongly with GLT1 amino acid residues 493-508 (" $\alpha 73 \mathrm{kDa}$ ") found a low level (6-9\% of the expression in astrocytes) of regionally limited expression in neuronal membranes in certain synaptic sites, for example in axospinous synapses in the stratum radiatum and in the inner third of the stratum moleculare of area dentata (Chaudhry et al., 1995). However, later review of these data revealed that the apparent expression associated with neuronal membranes was not significantly above background levels (Danbolt, 2001). A discrepancy that has emerged is that although immunocytochemical studies have failed to detect GLT1 in neurons in the brain, in situ hybridization studies have shown that mRNA for GLT1 is widely expressed in neurons in the brain (Torp et al., 1995; Berger and Hediger, 1998).

Working with nearly pure cultures of neurons derived from embryonic rat forebrain, we found a high-affinity glutamate uptake system that was comparable in activity to that present in synaptosomes or in astrocytes in culture, but whose pharmacology was distinct from that of the neuronal transporter EAAC1 and most closely resembled that of the putatively astrocytic transporter GLT1 in being readily inhibited by dihydrokainate (Wang 
et al., 1998a). The goal of the present study was to determine the molecular basis of transport in forebrain neurons by screening a cDNA library prepared from neuronal cultures for transporters with homology to the known glutamate transporters.

Preliminary reports of this work have appeared (Chen et al., 1998, 1999, 2000).

\section{MATERIALS AND METHODS}

Tissue culture. Neuronal cultures were prepared from embryonic day 16 Sprague Dawley rat fetuses using methods similar to those previously described (Rosenberg, 1991) but with modifications to facilitate the production of nearly pure neuronal cultures (Wang et al., 1998a,b). Although these cultures are primarily derived from cerebral cortex, they also are derived from hippocampus and deep gray structures and are more accurately referred to as forebrain cultures. Cultures were initially plated on poly-L-lysine coated 24-well plastic plates (Costar, Cambridge, MA) using an 80:10:10 (v/v) mixture of DMEM (catalog \#11960-010; Invitrogen, Grand Island, NY), Ham's F-12 (catalog \# N-4888; Sigma, St. Louis, MO), and heat-inactivated iron-supplemented calf serum (catalog \#A2151; HyClone, Logan, UT), containing $2 \mathrm{~mm}$ glutamine, $25 \mathrm{~mm}$ HEPES, $24 \mathrm{U} / \mathrm{ml}$ penicillin, and $24 \mu \mathrm{g} / \mathrm{ml}$ streptomycin in a $5 \% \mathrm{CO}_{2}$ (balance air) incubator at $36^{\circ} \mathrm{C}$. Cell proliferation was inhibited by exposure to $5 \mu \mathrm{M}$ cytosine arabinoside at $24 \mathrm{hr}$ in vitro for $72 \mathrm{hr}$. On the fourth day of culture, the medium was completely removed and replaced with $90 \%$ MEM, $10 \%$ NuSerum IV (Collaborative Research, Bedford, MA), $2 \mathrm{~mm}$ glutamine, $5 \mathrm{~mm}$ HEPES, containing $10 \mu \mathrm{g} / \mathrm{ml}$ superoxide dismutase (Roche Molecular Biochemicals, Indianapolis, IN) $1 \mu \mathrm{g} / \mathrm{ml}$ catalase (Sigma CV-40), total glucose $11 \mathrm{~mm}$, and total sodium bicarbonate $9.3 \mathrm{~mm}$, plus 2\% B27 supplement (Invitrogen 17504-036). Medium was not subsequently changed. To minimize evaporation, culture dishes were kept on "wet dishes" containing a filter paper pad that was always saturated with water. The immunochemical characterization of these cultures has been described previously (Wang et al., 1998a). Contamination by astrocytes was determined by immunochemical labeling with anti-glial fibrillary acidic protein antibody and was found to be $<0.2 \%$ of total cells.

Library screening and RT-PCR. Total RNA $(2.1 \mathrm{mg})$ was extracted from $21 \mathrm{~d}$ in vitro neuronal cultures using Tri-Reagent (Molecular Research Center, Inc., Cincinnati, OH). From this RNA, $11 \mu \mathrm{g}$ of poly(A) RNA was isolated using the Message Maker System (Invitrogen, Rockville, MD). The SuperScript Plasmid System (Invitrogen) was used to generate a cDNA library from $6 \mu \mathrm{g}$ of this mRNA ( $3 \mu \mathrm{g} /$ reaction). From two bulk ligations (300 ng of pCMVSPORT 2 vector, NotI-SalI cut, and $48 \mathrm{ng}$ of cDNA per $120 \mu \mathrm{l}$ of ligation), followed by electroporation into the ElectroMAX DH10B cells, $7 \times 10^{7}$ primary clones were produced. Slightly $>10^{7}$ primary clones were expanded by bacterial culture in a semisolid agarose solution to $10^{12}$. A portion of this bacterial stock was grown at $30^{\circ} \mathrm{C}$ in Terrific Broth containing ampicillin. The cDNA inserts from 14 randomly picked clones were sized using PCR and the SP6 and $\mathrm{T} 7$ primers. The average insert size of these 14 clones was $1.4 \mathrm{~kb}$.

We used a $5^{\prime}$ primer in the $5^{\prime}$-untranslated region (UTR) of the GLT1 cDNA (CGCCATGGCATCAACCGAGGG) to perform RT-PCR reactions with different $3^{\prime}$ primers according to the sequences of $3^{\prime}$-UTRs of GLT1a (CCTTTTGTAAAGGAAGCCTGTTT) and GLT1b (AGCTTGGGTGACATGATTCCTTAC) on mRNAs from neuronal cultures. Bands of $1.8 \mathrm{~kb}$ were obtained in both reactions, purified, and cloned into the TOPO-TA vector (Invitrogen), sequenced, and found to be GLT1 clones with the same $5^{\prime}$ end and different $3^{\prime}$ ends. The longest clones obtained from RT-PCR were then subcloned into pcDNA3 vector (Invitrogen) for expression studies in COS-7 cells (Gluzman, 1981).

Polyclonal antibodies. To differentiate the expression of GLT1a and GLT1b proteins, a polyclonal antibody against the synthetic peptide ECKVPFPFLDIETCI corresponding to the last 15 amino acids of GLT1b conjugated to keyhole limpet hemocyanin was generated in rabbits (Research Genetics, Huntsville, AL). N-terminal directed antibody was also generated against the peptide MASTEGANNMPKQVE (amino acids $1-15$ of GLT1) conjugated at its C terminus. Before being used in immunocytochemistry and immunoblot analysis the antisera were affinity-purified using peptide-binding columns. Polyclonal antibody against the C terminus of GLT1a protein based on the published sequence (amino acid 559-573 of GLT1) was generously provided by Dr. J. Rothstein (Johns Hopkins University) and has been previously characterized with respect to its specificity and localization in brain (Rothstein et al., 1994). We hereafter refer to these antibodies as anti-cGLT1b, anti-nGLT1, and anti-cGLT1a antibodies, respectively.

Light microscopic immunocytochemistry of cultured neurons. Neuronal cultures were grown on glass coverslips for 15-21 d. Cells were fixed with $4 \%$ paraformaldehyde in HBSS for 10 min at room temperature and then rinsed three times with Tris-buffered saline (TBS buffer) containing 50 mM Tris-HCl, $\mathrm{pH} 7.4$, and $150 \mathrm{~mm} \mathrm{NaCl}$. 4\% normal goat serum in TBS buffer with $0.1 \%$ Triton X-100 (TBS-T) was used to block nonspecific protein binding sites and to permeabilize cells. Antibodies were used at $140 \mathrm{ng} / \mathrm{ml}$ (anti-cGLT1a), $3.2 \mu \mathrm{g} / \mathrm{ml}$ (anti-cGLT1b), and $1.5 \mu \mathrm{g} / \mathrm{ml}$ (antinGLT1), respectively, in $2 \%$ normal goat serum in TBS-T. Cells were incubated in primary antibody solution at $4^{\circ} \mathrm{C}$ overnight, washed three times with TBS-T, and detected with goat anti-rabbit IgG conjugated with Oregon Green (Molecular Probes, Eugene, OR) at 1:500 dilution. Coverslips were then mounted with Fluoromount G (Fisher Scientific, Pittsburgh, PA) and examined by fluorescent microscopy or confocal microscopy. Controls were performed for each antibody by blocking with $50 \mu \mathrm{M}$ peptide against which the antibody was generated, by using preimmune serum at 1:500 dilution, as well as by omitting primary antibodies.

Light and electron microscopic immunocytochemistry on tissue sections. Sprague Dawley rats of postnatal days 24 and older were anesthetized deeply, using Nembutal $(50 \mathrm{mg} / \mathrm{kg})$, then transcardially perfused with a mixture of aldehydes. Aldehyde mixtures consisted of $4 \%$ paraformaldehyde alone or combined either with acrolein $(3 \%)$ or glutaraldehyde $(0.1-2 \%)$ and buffered using $0.1 \mathrm{M}$ phosphate $(\mathrm{PB})$ or cacodylate. A total of eight neocortices and hippocampi were sectioned at $40 \mu \mathrm{m}$ using a vibratome within $1 \mathrm{~d}$ after transcardial fixation. Sections were treated for 30 min with $1 \%$ sodium borohydride/ $\mathrm{PB}$, to terminate the cross-linking actions of the aldehydes, then rinsed repeatedly using $0.1 \mathrm{M} \mathrm{PB}$, and stored in $0.01 \mathrm{M} \mathrm{PB}$ containing $0.9 \%$ sodium chloride (saline) (PBS) and $0.05 \%$ sodium azide.

The pre-embedding silver-intensified colloidal gold (SIG) procedure was done as described previously (Chan et al., 1990; Aoki et al., 1999), using the same dilutions of the primary antisera, biotinylated secondary antibodies directed against rabbit IgGs, $1.4 \mathrm{~nm}$ colloidal gold-conjugated anti-biotin IgG (Goldmark, Phillipsburg, NJ) and a silver-intensification kit (IntensEM; Amersham Biosciences, Arlington Heights, IL). Endogenous zinc was chelated by injecting sodium diethyldithiocarbamate (1 $\mathrm{gm} / \mathrm{kg}$, i.p.), $15 \mathrm{~min}$ before transcardial perfusion of the animal (Veznedaroglu and Milner, 1992).

The above immunocytochemical procedure was assessed for specificity by using three controls: incubating sections with preimmune serum or simultaneously with the antibody and with $50 \mu \mathrm{M}$ of the 15 amino acid antigen peptide or with the unique 11 amino acid sequence of GLT1b.

Tissue processing for electron microscopy was done as previously described (Chan et al., 1990; Aoki et al., 1999), using EMBED812 or Epon-Spurr (Electron Microscopy Sciences, Fort Washington, PA) as the embedding medium. Fixation with osmium tetroxide also was omitted, to minimize loss of SIG and also to minimize electron density of PSDs, caused by the accumulation of osmium over the plasma membrane. In lieu of osmium tetroxide, ultrastructural preservation and visualization of membranes was achieved by the osmium-free procedure developed by Phend et al. (1995) and Matsubara et al. (1996). In brief, 40-mm-thick sections were post-fixed and counterstained with a series of solutions, consisting of the following: tannic acid, uranyl acetate, iridium tetrabromide, and para-phenylenediamine- $\mathrm{HCl}$, each made in a maleate buffer. These sections were infiltrated with Epon, flat-embedded between two sheets of Aclar plastic, then capsule-embedded for ultrathin sectioning. Ultrathin sections were collected serially onto Formvar-coated grids (50 or 200 mesh, thin bars). These sections were counterstained minimally with lead citrate ( $30 \mathrm{sec}$, using Reynold's lead citrate), to facilitate identification of processes and synapses without loss of SIG particles.

Sampling was performed strictly from the tissue-resin interface, where penetration by immunoreagents could be expected to be optimal. In addition, sampling was chosen to be from the neuropil residing between perikarya and blood vessels of layer 1 , because this layer contains the highest density of synapses, most of which are glutamatergic (Aoki et al., 1994).

Immunoblot analysis. Freshly obtained adult rat brain tissue was homogenized with a Brinkman Polytron in ice-cold homogenization buffer containing $5 \mathrm{mM} \mathrm{MgCl}_{2}, 5 \mathrm{~mm}$ EGTA, $50 \mathrm{~mm} \mathrm{KCl}, 17 \mu \mathrm{g} / \mathrm{ml}$ leupeptin, $1 \mathrm{~mm}$ phenylmethylsulfonyl fluoride, and $5 \mathrm{~mm}$ dithiothreitol in $20 \mathrm{~mm}$ Tris- $\mathrm{HCl}, \mathrm{pH}$ 7.4. Neuronal cultures of $21 \mathrm{~d}$ in vitro and GLT1transfected COS-7 cells were washed twice with HBSS before adding 
homogenization buffer and scraping off the culture. Homogenates of tissue and cell culture lysates were centrifuged at $14,000 \times g$ for $5 \mathrm{~min}$ at $4^{\circ} \mathrm{C}$. Pellets were then resuspended with the same buffer and homogenized with a Teflon homogenizer at full speed for $1 \mathrm{~min}$, and centrifuged at $14,000 \times g$ for $15 \mathrm{~min}$ at $4^{\circ} \mathrm{C}$. Membrane protein pellets were then solubilized in $1 \%$ SDS and stored at $-20^{\circ} \mathrm{C}$. The protein concentration was determined with a protein assay kit (Pierce, Rockford, IL). Aliquots of membrane protein were dissolved in sample buffer (62.5 mM Tris, $\mathrm{pH}$ $6.8,10 \%$ glycerol, $1.6 \%$ SDS, and $640 \mathrm{~mm} \beta$-mercaptoethanol), separated on $7.5 \%$ SDS polyacrylamide gels (10 $\mu \mathrm{g} /$ lane $)$, and then transferred to polyvinylidene fluoride membranes (NEN Life Science Products, Boston, MA) by electroblotting. The gels were silver-stained to check for equal loading. Blots were incubated with primary antibodies (anticGLT1a at $14 \mathrm{ng} / \mathrm{ml}$, anti-cGLT1b at $1.6 \mu \mathrm{g} / \mathrm{ml}$ and anti-nGLT1 at 1 $\mu \mathrm{g} / \mathrm{ml}$ ) overnight at $4^{\circ} \mathrm{C}$ in $5 \%$ nonfat milk, $100 \mathrm{~mm}$ Tris, $\mathrm{pH} 7.5,306 \mathrm{~mm}$ $\mathrm{NaCl}$, and $0.01 \%$ Tween 20 , and then washed three times with Tris$\mathrm{NaCl}$-Tween buffer, incubated for $1 \mathrm{hr}$ with horseradish peroxidaseconjugated goat anti-rabbit IgG (Amersham Life Science) at 1:2500 dilution and washed again. Immunoreactive proteins were detected by enhanced chemiluminescence (NEN Life Science Products). For regional studies, adult rats were used. In one of three independent experiments, a blot was used that was obtained commercially (Chemicon, Temecula, CA). The blot was stripped with $62.5 \% \quad \beta$-mercaptoethanol and $2 \%$ SDS at $65^{\circ} \mathrm{C}$ and checked with enhanced chemiluminescence. Immunoreactivity using GLT1 antibodies was not changed significantly after stripping.

For experiments investigating GLT1 expression in astrocytes, standard procedures were followed for preparing cultures (McCarthy and de Vellis, 1980). At $60 \%$ confluence, cultures were treated with $250 \mu \mathrm{M}$ dibutyryl cAMP for $14 \mathrm{~d}$ with half-medium change every $3 \mathrm{~d}$. Membrane protein ( $5 \mu \mathrm{g}$ of protein per lane) was separated by $7.5 \%$ SDS-PAGE and immunoblotted with anti-cGLT1a or anti-cGLT1b antibodies.

Expression of GLT1 proteins in COS-7 cells. COS-7 cells were maintained at $37^{\circ} \mathrm{C}$ in a humidified $5 \% \mathrm{CO}_{2}$ incubator in DMEM (catalog \#11960-044; Invitrogen) supplemented with 10\% fetal bovine serum and nonessential amino acids (catalog \#11140-035; Invitrogen, diluted 1:100) in 24-well plates. At $\sim 80-90 \%$ confluency, cells were transfected with full-length coding sequences of GLT1a and GLT1b cDNA inserted in the pcDNA3 vector (Invitrogen) using Lipofectamine Plus reagent (Invitrogen). For each well, $500 \mathrm{ng}$ of DNA was incubated for $15 \mathrm{~min}$ with $2 \mu \mathrm{l}$ of Plus reagent in $100 \mu \mathrm{l}$ of DMEM, and then $100 \mu \mathrm{l}$ DMEM plus $1 \mu \mathrm{l}$ of Lipofectamine was added. Incubation continued for another $15 \mathrm{~min}$, after which $200 \mu \mathrm{l}$ DMEM was added and mixed and the whole added to each well of cells that had been washed once with DME. Cells were then incubated at $37^{\circ} \mathrm{C}$ with $5 \% \mathrm{CO}_{2}$ for $5 \mathrm{hr}$ before medium was changed back to normal growth medium, and cells were incubated for 48 $\mathrm{hr}$ before uptake study. For stable transfection of GLT1a and GLT1b, 1 $\mathrm{mg} / \mathrm{ml}$ of G418 (catalog \#15710-072; Invitrogen) was added to the growth medium. Cells were selected for 2-3 weeks before positive colonies were observed on the plates. Single colonies were picked out and grown in separate wells with medium containing $1 \mathrm{mg} / \mathrm{ml} \mathrm{G418.} \mathrm{Mem-}$ brane proteins were extracted from GLT1a- and GLT1b-transfected COS-7 cells, subject to SDS-PAGE, and immunoblotted with antiGLT1a and anti-GLT1b antibodies to confirm the expression of GLT1 proteins.

Northern blot analysis. Forebrain total RNA was extracted from postnatal day $1,10,27$, or adult (200 gm) Sprague Dawley rats using TRIReagent. Total RNA of $10 \mu \mathrm{g} /$ lane was separated by electrophoresis through a $1.1 \%$ agarose-formaldehyde gel, blotted onto a nylon membrane and hybridized to DNA probes representing 3 '-UTR regions of GLT1a [nucleotides 2182-2332 in the $3^{\prime}$-UTR, 460 bases $3^{\prime}$ to the stop codon (Fig. 1)] or GLT1b (nucleotides 1690-1989 in the $3^{\prime}$-UTR, immediately $3^{\prime}$ to the stop codon). DNA probes representing the $3^{\prime}$-UTR regions of GLT1a and GLT1b both recognized bands at $11 \mathrm{~kb}$.

Uptake studies. Glutamate uptake experiments were done $2 \mathrm{~d}$ after transfections. Previously published procedures were followed for measuring the uptake of glutamate (Wang et al., 1998a) into cultured COS-7 cells. Cells were exposed to tritiated L-glutamate either in the presence (sodium buffer) or absence (choline buffer) of sodium, and the radioactivity taken up by the cultures in the absence of sodium was subtracted from that taken up by the cultures in the presence of sodium to isolate sodium-dependent transport. In a time course study, we found that glutamate uptake was linear for at least $10 \mathrm{~min}$ in COS-7 cells expressing either GLT1a or GLT1b. In subsequent studies we chose a 5 min exposure to assure that initial uptake rates were being measured. Cells
A

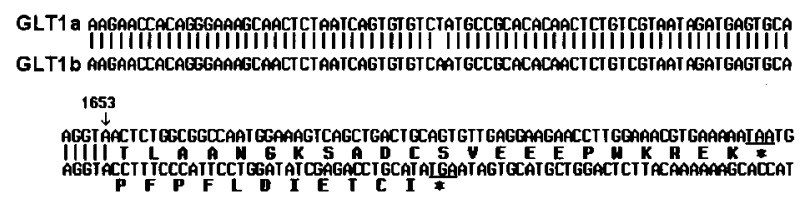

B
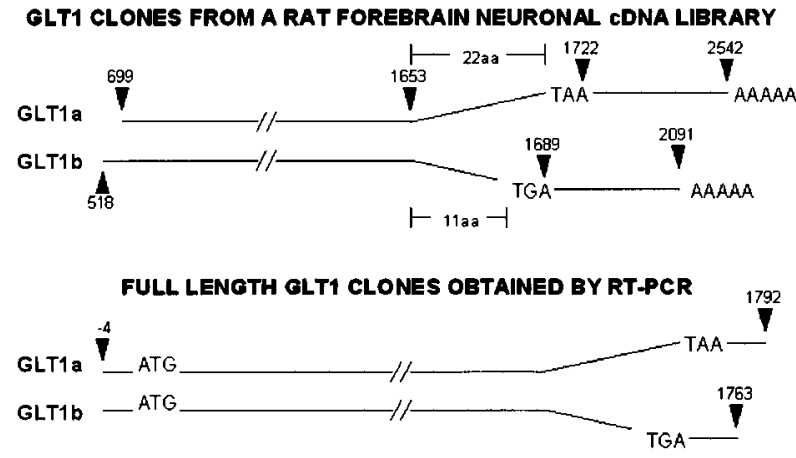

C

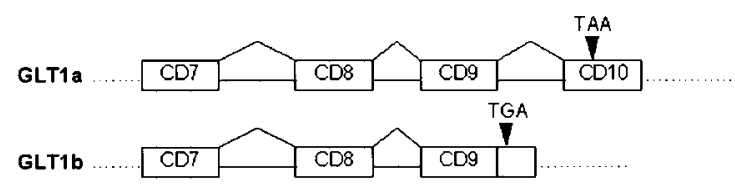

Figure 1. Sequence comparison of variant forms of GLT1. A, The $\mathrm{C}$-terminal sequence of the GLT1b clones obtained from a neuronal cDNA library is different from the published rat GLT1 (GLT1a) sequence U15098 (Roginski, 1996) in that the last 22 amino acids of GLT1a are replaced by a different stretch of 11 amino acids in GLT1b. $B$ shows clones obtained by library screening and by PCR. RT-PCR was performed using the 5' primer based on the known 5'-UTR GLT1 sequence and $3^{\prime}$ primers based on the $3^{\prime}$-UTR sequences of GLT1a and GLT1b cloned in this study. A $1.8 \mathrm{~kb}$ band was obtained with both pairs of primers and cloned into TOPO-TA vector (Invitrogen) and sequenced. Full-length clones were obtained with the structure shown that were subsequently used in expression studies. The base numbers used in this figure are according to the coding sequence. $C$ shows the variant form GLT1b is formed by termination of the coding sequence after exon 9.

grown in 24-well plates were washed twice with sodium or choline buffer at $37^{\circ} \mathrm{C}$ before being exposed at $37^{\circ} \mathrm{C}$ for $5 \mathrm{~min}$ to $\left[{ }^{3} \mathrm{H}\right] \mathrm{L}$-glutamate (catalog \#TRK445, Amersham; specific activity $63 \mathrm{Ci} / \mathrm{mmol}$ ). For the uptake study, a series of concentrations of L-glutamate was used; in the pharmacology studies, $0.5 \mu \mathrm{M}$ of total L-glutamate was used with selected concentrations of the glutamate transport inhibitors dihydrokainate (DHK), serine- $O$-sulfate (SOS), and L-trans-pyrrolidine-2,4dicarboxylate (PDC). The uptake assay was stopped by removal of the tracer solution and addition of ice-cold choline buffer containing $1 \%$ bovine serum albumin, followed by three more washes. Cells were then solubilized by adding $10 \%$ SDS, $1 \mathrm{ml} /$ well, and transferred into liquid scintillation vials followed by a $0.5 \mathrm{ml}$ wash of the well with distilled water. Radioactivity was assayed by liquid scintillation counting. The physiological saline for uptake studies contained (in mM): $140 \mathrm{NaCl}$ or choline chloride, $2.5 \mathrm{KCl}, 1.2 \mathrm{CaCl}_{2}, 1.2 \mathrm{MgCl}_{2}, 1.2 \mathrm{~K}_{2} \mathrm{HPO}_{4}, 10$ glucose, 5 Tris base, and 10 HEPES, pH 7.4, osmolality 300 (Garlin et al., 1995).

Data analysis. All the data are presented as mean \pm SD. Data from experiments determining $K_{\mathrm{m}}$ values for glutamate uptake were plotted by nonlinear regression using Prism software (GraphPad, Inc., San Diego, CA). The curves were best fitted by a single-site Michaelis-Menten model. $\mathrm{IC}_{50}$ values were determined using the one-site competition model. Inhibition constants were calculated from $\mathrm{IC}_{50}$ values according to the equation: $K_{i}=\mathrm{IC}_{50} /\left(1+[\mathrm{L}-\mathrm{Glu}] / K_{m} G l u\right)$. In this equation, the $K_{m}$ value used was the $K_{m}$ value for glutamate transport, and the concentration of substrate was $0.5 \mu \mathrm{M}$. 


\section{RESULTS}

Double-stranded plasmid DNA was isolated from a cDNA library made from nearly pure cultures of rat forebrain neurons and used in a solution-based hybridization method (Gene Trapper; Invitrogen) in an attempt to isolate known and novel glutamate transporters. Probes based on the highly conserved sequences NLVQACF and AAIFIAQ were used. These probes had been used previously to discover a new transporter, EAAT4, whose existence was inferred from discrepancies between the pharmacology of cerebellar synaptosomes and the known glutamate transporters (Fairman et al., 1995). Colony hybridization was performed with a mixture of full-length EAAC1 or GLT1 cDNA probes. Southern hybridization was performed on the 22 positive clones with whole EAAC1 and GLT1 cDNA probes. Nineteen were EAAC1 (seven were full-length clones), and three were partial GLT1 clones. Sequencing of these clones revealed no variant form or novel transporter. Another round of GeneTrapper technology was applied to enrich for GLT1 clones using a sequence close to the break point of the cDNA obtained in the first screen (GTCTTAGGTCTGATTGGATTC). Colony hybridization using a GLT1 cDNA probe yielded ten additional positive clones, all of which were partial GLT1 clones. Two clones were identical to the three GLT1 clones found in the first round of screening, and each contained bases starting with 699 of the published coding sequence (GenBank accession number U15098) (Pines et al., 1992; Kanner et al., 1993) and extending to base 2542 in the $3^{\prime}$-UTR before the poly(A) region. The other eight clones were identical to each other and represented a GLT1 variant with an altered sequence in the region coding for the $\mathrm{C}$-terminal end of the protein. These clones had the same nucleotide sequence from 518 to 1653 of the previously described GLT1 cDNA, whereas the sequence of the last 36 bases in the coding region was different from the last 69 bases of the original GLT1 cDNA and was similar to a previously published sequence derived from the mouse (GenBank accession number AB007812) (Utsunomiya-Tate et al., 1997). The 3'-UTR region of the variant form GLT1 was also different from that of the originally reported GLT1 and unlike the original form contained a poly(A) sequence (GLT1b; GenBank accession number AF451299). We here designate the original GLT1 form as "GLT1a," and the variant GLT1 form as "GLT1b." The sequence of GLT1a we have cloned from the rat neuronal culture library contains a longer 3'-UTR than the originally published GLT1 and extends to a poly(A) sequence (GLT1a; GenBank accession number AY069978).

The two different GLT1 clones are shown in Figure $1 A$. We were not able to obtain clones of either GLT1a or GLT1b containing the full-length coding sequence from the neuronal library. We therefore obtained the full-length coding sequence by RTPCR using specific C-terminal primers and a common N-terminal directed primer (Fig. 1B). A variant $\mathrm{N}$ terminus of GLT1 has also been cloned from mouse liver (Utsunomiya-Tate et al., 1997). Primers directed against the mouse $\mathrm{N}$-terminal variant and the rat C-terminal variants failed to produce PCR products from rat neuronal culture transcripts. RT-PCR was only successful when we used primers directed against either of the rat $\mathrm{C}$-terminal regions obtained by cloning and a primer against the $\mathrm{N}$-terminal region contained in the published sequence for rat. In addition, we performed 5'-rapid amplification of cDNA ends (RACE) using a set of primers in the $5^{\prime}$ region of the GLT1 coding sequence on rat neuronal mRNA to find possible $5^{\prime}$ variant forms. We sequenced over 50 5'-RACE clones, and all were the same
A

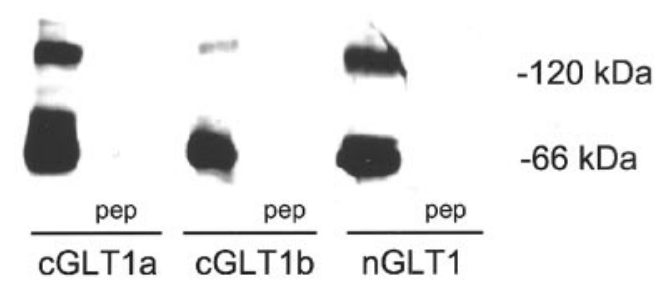

B

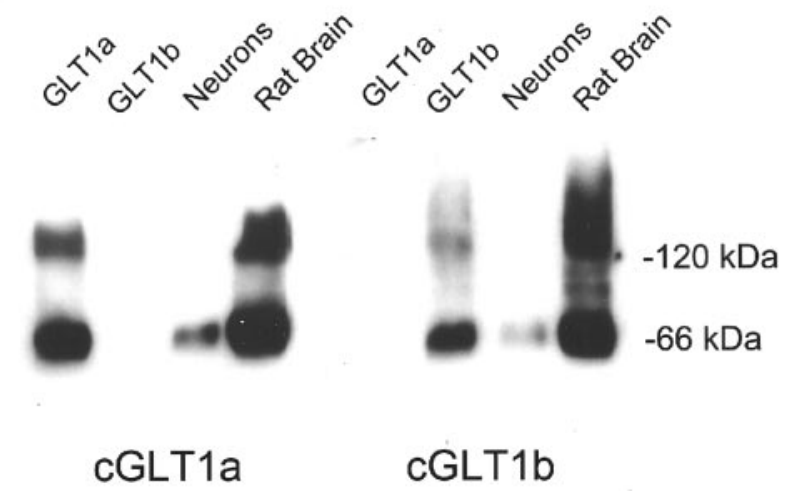

Figure 2. Immunoblot characterization of GLT1 antibodies. $A$, Membrane proteins from adult rat brain were analyzed by immunoblot as described (Materials and Methods) using anti-cGLT1a, anti-cGLT1b, and anti-nGLT1 antibodies ( $c G L T 1 a, c G L T 1 b$, and $n G L T 1$, respectively). All the anti-GLT1 antibodies recognized bands at $\sim 66 \mathrm{kDa}$ and also at $\sim 130$ $\mathrm{kDa}$. Immunoreactivity was completely abolished when each antibody was preabsorbed with $50 \mu \mathrm{M}$ of the peptide antigen ( $p e p$ ). Control experiments were done with heterologous peptides (anti-nGLT1 antibody preabsorbed with cGLT1a peptide, anti-cGLT1a antibody preabsorbed with cGLT1b peptide, and anti-cGLT1b antibody preabsorbed with cGLT1a), which had no effect on the immunoreactivity in brain membrane immunoblots. $B$, Immunoblot analysis showed that anti-cGLT1a and anticGLT1b antibodies have no cross-reactivity. Membrane proteins from cultured neurons, rat brain tissue, and COS-7 cells stably expressing GLT1a and GLT1b proteins were subjected to SDS-PAGE and immunoblotted with anti-cGLT1a and anti-cGLT1b antibodies. Anti-cGLT1a antibody ( $c$ GLT1a) recognized bands in GLT1a transfected COS-7 cells as well as in neuronal cultures and rat brain tissue, but not in GLT1b transfected COS-7 cells. Anti-cGLT1b antibody $(c G L T 1 b)$ recognized bands in a GLT1b stable transfectant COS-7 cell line, in neuronal cultures and in rat brain membranes, but not in GLT1a-transfected cells.

sequence as the published GLT1 clones, consistent with the earlier finding that the N-terminal variant is liver specific. Comparison of the coding region of GLT1b with the genomic sequence determined for human GLT1 (Meyer et al., 1997) reveals that the GLT1b sequence lacks exon 10, and the coding region terminates in the intron after exon 9 (Fig. 1C).

Using the sequence information from the partial GLT1b clone, we produced a polyclonal rabbit antibody (Fig. 2). An antibody was also raised against the $\mathrm{N}$-terminal region. In addition, an antibody against the C-terminal region of GLT1a was kindly provided by Dr. Jeff Rothstein. When used to immunoblot rat brain membranes, these three antibodies each produced a band at $\sim 66 \mathrm{kDa}$ as well as at $130 \mathrm{kDa}$ (Fig. $2 A, B$ ). It is likely that the higher mass band represents a dimer of the lower molecular mass form of the protein. The specificity of these antibodies was tested 
by inclusion of peptide against which the antibody was directed, and in each case the peptide completely blocked the appearance of the bands at 66 and $130 \mathrm{kDa}$ (Fig. $2 A$, pep). We found that the 11 amino acid peptide based on the unique $\mathrm{C}$-terminal sequence of GLT1b was also able to completely block labeling of the blot by the anti-cGLT1b antibody. As a further test of the specificity of the antibodies, COS-7 cells were transfected with GLT1a and GLT1b cDNA in the pCDNA3 expression vector (Invitrogen), and lysates from GLT1a-expressing cells (Fig. 2B, GLT1a), GLT1b-expressing cells (Fig. 2B, GLT1b), neuronal cultures (Fig. $2 B$, neurons), and brain were tested for immunoreactivity with anti-cGLT1a and anti-cGLT1b antibodies (Fig. 2B, cGLT1a, $c G L T 1 b)$. Anti-cGLT1a antibody reacted only with COS-7 cells transfected with GLT1a, neuronal cultures, and rat brain. AnticGLT1b antibody reacted only with COS-7 cells transfected with cGLT1b, neuronal cultures, and rat brain. These studies establish the specificity of the anti-cGLT1b antibody and confirm the specificity of the anti-cGLT1a antibody that has been previously demonstrated (Rothstein et al., 1994). These studies also demonstrate the expression of both forms of GLT1 in neuronal cultures.

These cultures contain very few astrocytes, and so the expression observed in the immunoblots was unlikely to be attributable solely to expression in astrocytes. To directly address this question, we used these three antibodies to study the localization of GLT1 in the neuronal cultures. GLT1a and GLT1b were clearly expressed on processes of neurons in these cultures, demonstrated by the immunocytochemical pattern of staining with anticGLT1a and anti-cGLT1b as well as by anti-nGLT1 antibodies (Fig. 3). All three of these antibodies produced a punctate staining pattern (Fig. $3 A, C, E$ ) that could be completely blocked by inclusion of the peptide against which the antibody was directed (Fig. 3B,D,F).

The studies so far revealed that the variant form GLT1b was significantly expressed in neurons in culture. The next question we addressed was whether the variant form GLT1b had similar functional properties to GLT1a. COS-7 cells transfected with plasmids expressing GLT1a or GLT1b reliably induced a large increase in sodium dependent uptake activity. The $K_{\mathrm{m}}$ values for GLT1a and GLT1b were similar, at $28 \pm 3 \mu \mathrm{M}$ for GLT1a (two experiments) and $32 \pm 3 \mu \mathrm{M}$ for GLT1b (two experiments). Vector alone produced very little sodium dependent transport activity. In two experiments, the transport activity seen with vector alone was $0.6 \%$ of that obtained in COS-7 cells expressing GLT1a or GLT1b.

GLT1 has a distinctive pharmacology, and the transport associated with cortical synaptosomes (Ferkany and Coyle, 1986; Robinson et al., 1993; Koch et al., 1999) and forebrain neurons in culture (Wang et al., 1998a) has been shown to resemble GLT1 in that it is inhibitable by DHK (Table 1). However, an anomaly has been that although SOS is a relatively weak ( $K_{\mathrm{i}}$ value, 1157) inhibitor of the human GLT1 homolog EAAT2 (Arriza et al., 1994), it is of moderate potency in neuronal cultures and in oocytes expressing GLT1 (Wang et al., 1998a) (Table 1). We tested the potency of DHK, SOS, as well as the pan-transporter inhibitor PDC against glutamate transport mediated by GLT1a and GLT1b expressed in COS-7 cells (Fig. 4). In the experiment shown, the $K_{\mathrm{i}}$ values for DHK, SOS, and PDC against GLT1a were 52, 100, and $5.3 \mu \mathrm{M}$, respectively. Against GLT1b these values were 45,112 , and $6.3 \mu \mathrm{M}$, respectively.

Table 1 summarizes the experiments with GLT1a and GLT1b expression in COS-7 cells, and several conclusions can be drawn. First, there was no significant difference $(p>0.05)$ between

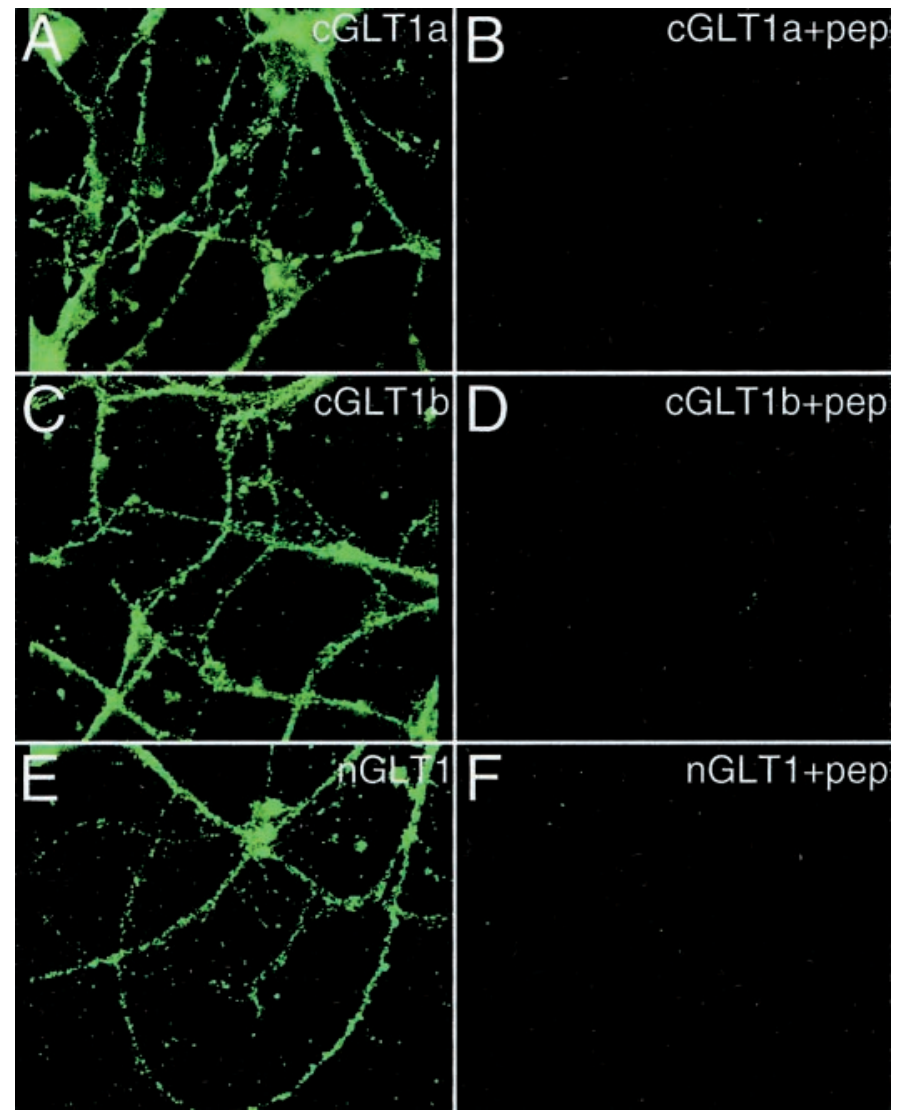

Figure 3. Immunocytochemistry of GLT1a and GLT1b expression in cultured forebrain neurons. $A, C, E$, Cultured neurons at $18 \mathrm{~d}$ in vitro immunostained with anti-cGLT1a $(140 \mathrm{ng} / \mathrm{ml})(A)$, anti-cGLT1b (3.2 $\mu \mathrm{g} / \mathrm{ml})(B)$, and anti-nGLT1 $(1.5 \mu \mathrm{g} / \mathrm{ml})(C)$ antibodies. All GLT1 antibodies detected immunoreactivity on neuronal processes and plasma membranes in a similar punctate pattern, suggesting synaptic localization of GLT1 proteins. Note that immunostaining by anti-cGLT1a and anticGLT1b antibodies was not distinguishable. $B, D, F$, Immunoreactivity was completely blocked using an excess of peptide against which each GLT1 antibody was directed.

GLT1a and GLT1b with respect to the $K_{\mathrm{i}}$ values obtained for DHK, SOS, and PDC. Second, the $K_{\mathrm{i}}$ values obtained with COS-7 cells very closely resembled the values obtained in neuronal cultures, with the exception of SOS, for which a value in COS-7 cells in the present study was obtained that was approximately twice the value obtained in neurons in our previous study. Third, the $K_{\mathrm{i}}$ value for DHK was consistent with the value obtained in neuronal cultures, COS-7 cells, and cortical synaptosomes, but was six to seven times higher than we obtained in oocyte expression studies (Wang et al., 1998a). According to these results, glutamate transport in neuronal cultures can be almost completely accounted for by the expression of GLT1a and GLT1b in neurons in these cultures.

Previous studies have shown that in astrocyte cultures, in which neurons were not present, GLT1 mRNA and protein expression were barely detectable (Swanson et al., 1997; Schlag et al., 1998). In addition, these studies showed that GLT1a was markedly upregulated by exposure to neuron conditioned medium or to dibutyryl cAMP. It was of interest to determine whether GLT1b as well as GLT1a were both downregulated in astrocytes without neurons present and whether they would both be coordinately upregulated. In three experiments we confirmed that astrocyte 


\begin{tabular}{|c|c|c|c|c|c|}
\hline & DHK & L- $\alpha-\mathrm{AA}$ & PDC & KA & SOS \\
\hline GLT1a (rat; in COS-7 cells) & $53 \pm 3^{a}$ & ND & $5 \pm 1^{a}$ & ND & $107 \pm 6^{a}$ \\
\hline GLT1b (rat; in COS-7 cells) & $47 \pm 6^{a}$ & ND & $6 \pm 2^{a}$ & ND & $126 \pm 9^{a}$ \\
\hline GLT1 (rat; in oocytes) ${ }^{b}$ & $8^{a}$ & $>1 \mathrm{mM}^{a}$ & ND & ND & $312^{c}$ \\
\hline Neuronal cultures ${ }^{b}$ & $65^{a}$ & $>1 \mathrm{mM}^{a}$ & $5^{a}$ & $103^{a}$ & $56^{a}$ \\
\hline \multicolumn{6}{|l|}{ Cortical synaptosomes (rat) ${ }^{d}$} \\
\hline High efficiency site & $110^{a}$ & $720^{a}$ & $2.1^{a}$ & $72^{e}$ & $2.6^{e}$ \\
\hline Low efficiency site & & & & $3500^{e}$ & $55^{e}$ \\
\hline
\end{tabular}

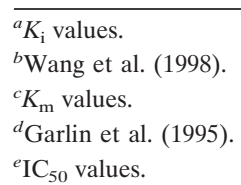

cultures expressed little GLT1a and also that they expressed little GLT1b. After stimulation with $250 \mu \mathrm{M}$ dibutyryl cAMP for $14 \mathrm{~d}$ we found that the expression of both GLT1a and GLT1b were greatly increased (Fig. 5).

The starting point of this work was to characterize the glutamate transporters present in nearly pure cultures of rat forebrain neurons that contained very few astrocytes. In these cultures we demonstrated expression of GLT1a, as well as a variant form, GLT1b. This variant form has not previously been shown to be significantly expressed in the brain, although a previous study demonstrated by RT-PCR that transcripts for GLT1b were detectable in RNA derived from the mouse brain (Utsunomiya-Tate et al., 1997). To assess the significance of GLT1b as a variant form of GLT1, we next investigated the expression of GLT1b mRNA and protein in the rat brain. For Northern blot analysis, we exploited the fact that the two variant forms possess completely different 3'-UTR sequences [GenBank accession numbers AF451299 (GLT1b) and AY069978 (GLT1a)]. Therefore, probes directed at the $3^{\prime}$-UTR regions should be able to distinguish between the two transcripts. In a developmental survey we found that the expression of both GLT1a and GLT1b increased with age (Fig. 6). By P10, strong signals for GLT1a and GLT1b were present. Interestingly, a $3.3 \mathrm{~kb}$ transcript was detectable using the GLT1b probe; at higher levels of loading, a transcript at similar, but different, relative mass $(3.5 \mathrm{~kb})$ was detectable using the GLT1a probe (data not shown). The experiment shown is representative of four independent experiments that were performed. To study protein expression, a regional survey by immunoblot analysis was performed (Fig. 7). Heavy expression of GLT1b as well as GLT1a was found in the cortex, hippocampus, striatum, thalamus, and midbrain. The patterns of expression for GLT1b and GLT1a were similar, but nonidentical. The experiment shown is one of three independent experiments that were performed.

These Northern and immunoblot studies demonstrated that GLT1b transcript and protein are significantly expressed in the normal rat brain. The next question we addressed was the cellular localization of GLT1b. The immunoblot and immunocytochemical studies reported in Figures 2 and 3 established that the variant GLT1b protein was expressed in forebrain neurons in tissue culture. The studies reported in Figure 5 demonstrated the expression of GLT1b in astrocytes in culture as well. GLT1a, which has been shown previously to be exclusively an astrocyte transporter in the normal, mature brain, was found together with GLT1b in neurons in culture. Because the expression of GLT1a in cultured neurons is possibly caused by some aspect of the culture procedure and not representative of its expression in vivo, the question was asked then whether in vivo GLT1b would also be localized to astrocytes exclusively or whether it would be found to be expressed in neurons in vivo.

To answer this question, electron microscopic localization studies were performed in rat brain using pre-embedding immunocytochemistry with detection by SIG (Fig. 8). Figure $8 A$ shows an example of labeled terminals. SIG particles occurred at sites away from and adjacent to the plasma membrane. In contrast, labeling within astrocytes occurred predominantly at the membrane (portion facing asymmetric synapse indicated by an asterisk). In the panel shown in Figure $8 B$, three PSDs are indicated by open arrows. Astrocytes (LAs) are labeled in several locations. Asterisks indicate labeling adjacent to synapses. Figure $8 C$ again shows a labeled astrocyte (LAs) as well as an unlabeled astrocyte (UAs). A dendritic shaft is labeled LSh and contains three particles. Silver-enhanced gold particles were close to or immediately adjacent to membranes of astrocytes, but were more often located in the cytoplasm, presumably associated with cytoplasmic membranes, in neurons. Preadsorption of the anti-cGLT1b antibody abolished the SIG immunolabeling completely. These results demonstrate that GLT1b protein is detectable in neuronal elements, as well as in astrocytes, in the normal mature brain.

\section{DISCUSSION}

In this report we provide evidence that a variant form of GLT1, designated GLT1b, as well as the originally described form, GLT1a, is significantly expressed in forebrain neurons in tissue culture. The expression of these two forms accounts for the dihydrokainate-sensitive glutamate transport displayed by these cultures (Wang et al., 1998a). Others have shown by single-cell PCR that transcripts for GLT1 are present in hippocampal cultures (Brooks-Kayal et al., 1998) and that GLT1a protein is expressed in hippocampal neurons in microcultures (Mennerick et al., 1998). In addition to demonstrating the presence of GLT1b in neurons in culture, the results of Northern blot and immunoblot analysis presented here also establish that GLT1b transcripts and protein are significantly expressed in the rat brain.

\section{Cellular localization of GLT1b}

Because neurons can induce the expression of GLT1a in astrocytes (Swanson et al., 1997; Schlag et al., 1998), it was possible that the expression of GLT1b in neurons in our cultures was a peculiarity of tissue culture not representative of its expression 

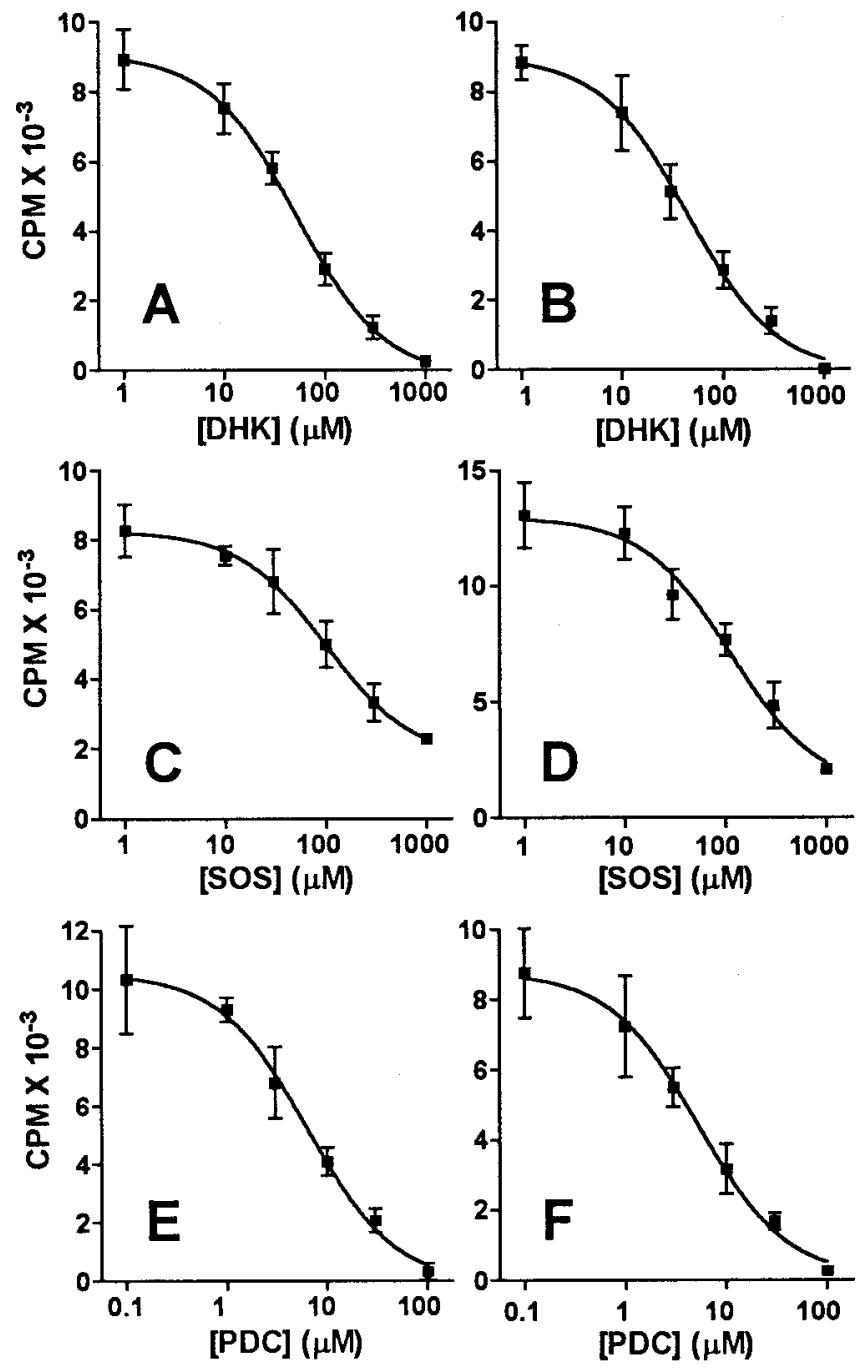

Figure 4. Effect of transport inhibitors on $\left[{ }^{3} \mathrm{H}\right] \mathrm{L}$-glutamate uptake in GLT1a- and GLT1b-transfected COS-7 cells. $A, B$, The effect of DHK on $\left[{ }^{3} \mathrm{H}\right] \mathrm{L}$-glutamate uptake by GLT1a $(A)$ and GLT1b $(B)$. In this particular experiment the $\mathrm{IC}_{50}$ values for GLT1a and GLT1b were 52 and $45 \mu \mathrm{M}$, respectively. $C, D$, The effect of SOS on $\left[{ }^{3} \mathrm{H}\right] \mathrm{L}$-glutamate uptake by GLT1a $(C)$ and GLT1b $(D)$. The $\mathrm{IC}_{50}$ values for GLT1a and GLT1b were 100 and $102 \mu \mathrm{M}$, respectively. $E, F$, The effect of PDC on $\left[{ }^{3} \mathrm{H}\right] \mathrm{L}$-glutamate uptake by GLT1a $(E)$ and GLT1b $(F)$. The IC $_{50}$ values for GLT1a and GLT1b were 6.3 and $5.3 \mu \mathrm{M}$, respectively. In each case, results are single experiments representative of at least four experiments that were performed (Table 1).

patterns in the brain, in which GLT1 protein has been found to be mainly associated with astrocytes (Rothstein et al., 1994; Chaudhry et al., 1995; Lehre et al., 1995). However, a sensitive in situ hybridization study in the brain showed widespread expression of mRNA for GLT1 in neurons (Berger and Hediger, 1998). Our demonstration of GLT1b protein in neurons in vivo is consistent with and, in fact, anticipated by this demonstration of GLT1 transcripts in neurons. Whether the GLT1 transcripts that are present represent primarily GLT1a or GLT1b remains a question, however. It should be possible to address this issue using variant specific probes targeting the different 3 '-UTRs of the two forms.

A previous study that used several different antibodies directed against different regions of GLT1 shared by the two variant forms failed to detect immunolabeling in neurons (Lehre et al., 1995).

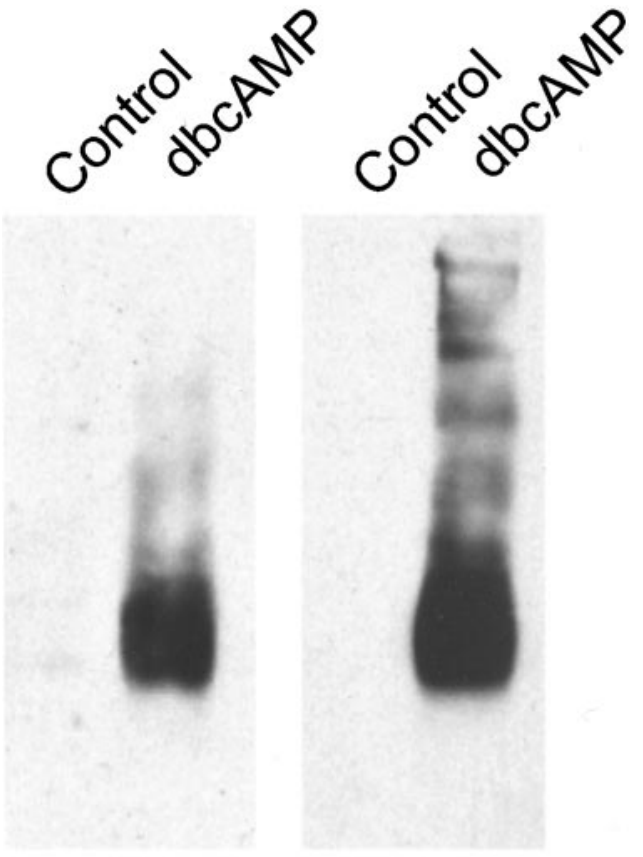

\section{GLT1a GLT1b}

Figure 5. Similar upregulation of GLT1a and GLT1b in astrocytes in response to dibutyryl cAMP. Astrocyte cultures contained undetectable levels of GLT1a or GLT1b (Control). After treatment with $250 \mu \mathrm{M}$ dibutyryl cAMP $(d b c A M P)$ for $14 \mathrm{~d}$, both GLT1a and GLT1b were significantly upregulated. Membrane protein $(5 \mu \mathrm{g})$ solubilized in $1 \%$ SDS was loaded in each lane.

At the light microscopic level, this can be simply explained by the preponderant astrocyte labeling obscuring the neuronal labeling, as has been noted in an in situ hybridization study of GLT1 mRNA (Berger and Hediger, 1998). At the EM level, the failure of antibodies against shared epitopes to detect neuronal labeling cannot be explained in this way. Three considerations are relevant. First, it has been shown that antibodies of proven specificity against different regions of a molecule may produce very different patterns of labeling, for reasons that are unclear (Aoki et al., 1999). Second, fixation techniques are critical, and we found best preservation of antigen using paraformaldehyde and avoiding glutaraldehyde. Third, care needs to be taken to use ultrathin sections close to the surface of the stained tissue section because only at the surface is penetration of reagents optimal. For these specific reasons (varying results with different antibodies, denaturation of antigen by the fixation conditions, and limited penetration of reagents into tissue), the failure of an antibody to detect an antigen cannot be taken as evidence excluding the presence of that antigen. Based on our rigorous demonstrations of the specificity of the anti-GLT1b antibody, the fact that it is clearly expressed in neurons in culture, the presence of immunoreactivity in neurons using this antibody in vivo, and the previous demonstration of mRNA for GLT1 in neurons throughout the brain (Berger and Hediger, 1998), we feel confident that GLT1b is, in fact, expressed in neurons.

Despite the evidence for glutamate uptake in excitatory terminals (Iversen and Storm-Mathisen, 1976; Divac et al., 1977; Storm-Mathisen, 1977; Storm-Mathisen and Iversen, 1979; Cuenod et al., 1982; Gundersen et al., 1993; Gundersen et al., 1995), the identification of the responsible transporter 
P1 P10 P27 ad P1 P10 P27 ad

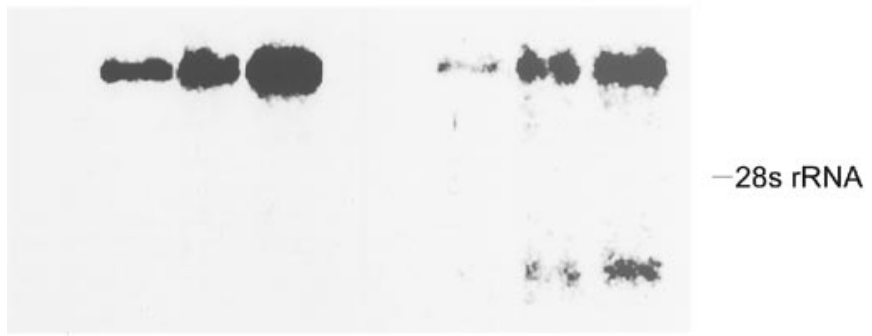

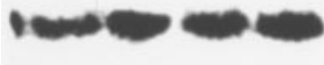

GLT1a

\section{GLT1b}

Figure 6. Expression of GLT1a and GLT1b mRNA during development. Total RNA was extracted from the forebrain of postnatal day $1(P 1)$, day 10 (P10), day 27 (P27), or adult ( $a d ; 200 \mathrm{gm})$ Sprague Dawley rats. Ten micrograms of total RNA was loaded per lane. DNA probes representing 3'-UTR regions of GLT1a or GLT1b hybridized to RNA at $\sim 11 \mathrm{~kb}$. The GLT1b probe clearly recognized another RNA $\sim 3 \mathrm{~kb}$. At longer exposure times, a $3.5 \mathrm{~kb}$ band was seen with the GLT1a probe (data not shown). Expression of both GLT1a and GLT1b progressively increased through development.

has been elusive (Danbolt, 2001). Our finding of GLT1b in axon terminals suggests that GLT1 may be an important presynaptic transporter.

Ventura and Harris (1999) found that $\sim 60 \%$ of excitatory synapses in the hippocampus had astrocytic processes opposed to them, and of these, astrocytic processes surrounded less than half of the synaptic apposition. Furthermore, astrocytic processes occurred along the path between only $\sim 33 \%$ of neighboring synapses, whereas $66 \%$ of these paths were exclusively along neuronal membranes. Therefore, the presence of glutamate transporters presynaptically and postsynaptically in neurons is likely to be important in controlling spillover from occurring between excitatory synapses (Asztely et al., 1997; Rusakov and Kullmann, 1998). EAAC1 is expressed in a somatodendritic localization (Rothstein et al., 1994; Velaz-Faircloth et al., 1996; Coco et al., 1997; Shashidharan et al., 1997). An immunogold study in the macaque monkey demonstrated sparse distribution of EAAC1 in the postsynaptic density, at the edge, and in the perisynaptic zone

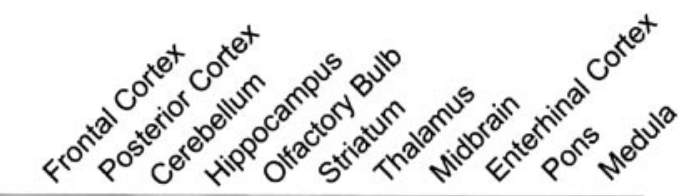

\section{GLT1a}

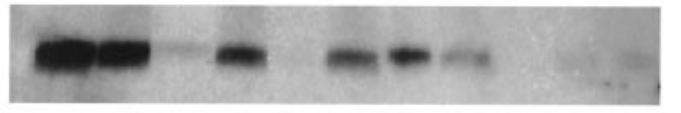

GLT1b

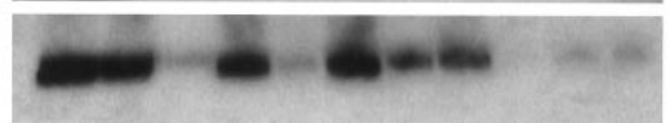

Figure 7. Regional distribution of GLT1a and GLT1b proteins in rat brain. Immunoblots representing different rat brain regions were probed with anti-cGLT1a or anti-cGLT1b antibodies. Both proteins were detected in all regions. Strongest expression was observed in the cerebral cortex.
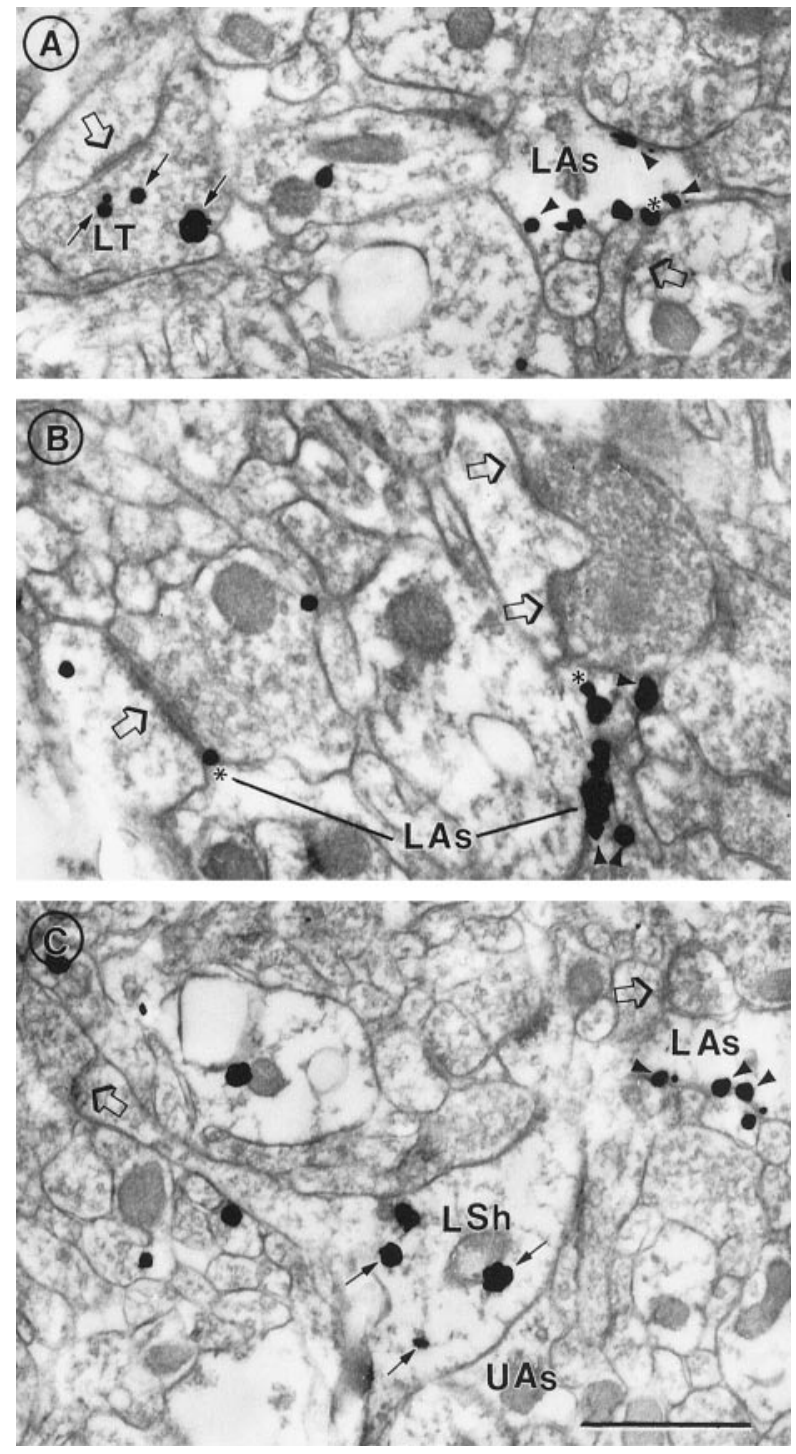

Figure 8. Anti-cGLT1b immunoreactivity in neurons and astrocytes of layer 1 of somatosensory cortex, as revealed by electron microscopic immunocytochemistry using SIG label. $A$, SIG label is present in an axon terminal $(L T)$ and in an astrocyte $(L A s)$. Here and in all other panels, SIG particles are indicated by arrows in neuronal elements and by arrowheads in astrocytes, whereas open arrowheads point to postsynaptic densities. SIG labeling is present along the plasma membrane of an astrocyte, including portions juxtaposed to asymmetric junctions (asterisk). B, An astrocyte is labeled $L A s$ at two sites adjacent to two different asymmetric synapses (asterisks). C, A shaft, possessing a contiguous spine in the same section, is labeled $L S h$. An astrocyte is labeled $L A s$, and SIG particles are located adjacent to the plasma membrane. Note that not all astrocytes are labeled (e.g., $C, U A s)$. Scale bar, $500 \mathrm{~nm}$.

of asymmetric synapses in the entorhinal cortex (He et al., 2000). The localization of GLT1b to the postsynaptic membranes of a subset of excitatory synapses suggests a possible role for GLT1 as well in the neuronal clearance of synaptically released glutamate. The extent of the expression of GLT1b in presynaptic terminals and postsynaptically in spines and dendrites can only be answered by a quantitative study of the expression of GLT1b in neurons, preferably with serial reconstruction of cellular elements. Such a study is currently in progress, but is beyond the scope of the present report. 


\section{Implications of the existence of a variant form of GLT1 for the physiology of glutamate transport}

It is well established that the $\mathrm{C}$ terminus of membrane proteins may interact with other proteins by way of specialized domains to form macromolecular complexes (Niethammer et al., 1996; Brakeman et al., 1997; Dong et al., 1997; Ziff, 1997; Kim and Huganir, 1999; Sheng and Pak, 1999; Sheng and Sala, 2001). The existence of C-terminal variants of GLT1 suggest that there may be different interacting networks for each form. Specifically, the last four amino acids of GLT1b constitute a PSD-95/DLG/ZO-1 domain-interacting consensus sequence lacking in GLT1a. It will be of great interest to determine whether GLT1b has interacting protein partners and whether these are distinct from the interacting protein partners of GLT1a.

\section{Ultrastructural localization of GLT1b in neurons}

A surprising finding of this work is that in neurons the SIG labeling was typically at sites removed from the plasma membrane. One interpretation of this finding is that GLT1b in neurons in the plasma membrane may be masked by membraneanchoring proteins that interact with the $\mathrm{C}$ terminus, competing with the $\mathrm{C}$ terminus directed antibody. Another possibility is that the bulk of the GLT1b in neurons is dormant and localized to cytoplasmic membranes until mobilized to the cell surface as a result of exposure to a signal, perhaps related to activity. This would be consistent with studies showing significant translocation of EAAC1 to the plasma membrane as a result of activation of protein kinase C (Dowd and Robinson, 1996; Davis et al., 1998).

\section{Developmental variation}

We used 3'-UTR-specific probes to assay separately GLT1a mRNA and GLT1b mRNA across development, and our finding of increasing postnatal expression is in basic agreement with a previous in situ hybridization study using probes directed against the coding sequence of GLT1 (Sutherland et al., 1996) and an immunocytochemical study using an anti-cGLT1a antibody (Furuta et al., 1997). The localization of GLT1a at greatest density in astrocyte membranes adjacent to synapses (Lehre and Danbolt, 1998) as well as in dendritic shafts and axon terminals (this study) suggests that the increasing expression of both GLT1a and GLT1b may be related to synaptic enrichment and activity in the postnatal period.

\section{Implications of variant forms of GLT1 in the pathophysiology of glutamate transport}

Glutamate efflux via glutamate transporters in neurons is a source of the extracellular glutamate that accumulates in ischemia (Szatkowski et al., 1990; Attwell et al., 1993; Lipton and Rosenberg, 1994). DHK has been shown recently to significantly block the release of glutamate during ischemia (Seki et al., 1999), and this finding might indicate a role for GLT1 expressed in neurons.

Glutamate transport and GLT1 protein expression are depressed in $\sim 50 \%$ of patients with sporadic amyotrophic lateral sclerosis. There is evidence suggesting that aberrant RNA processing of GLT1 transcripts underlies these defects (Lin et al., 1998). Because at least one familial neurodegenerative disease, frontotemporal dementia, has been shown to be caused by a mutation resulting in a defect in splicing (Poorkaj et al., 1998; Morris et al., 1999; Varani et al., 1999), the existence of a variant form of GLT1 raises the possibility that a mutation affecting the splicing of this protein might produce deleterious consequences.
In summary, two variant forms of GLT1 are expressed in neurons in culture and account for glutamate transport in these cultures. GLT1b, which we cloned from a neuronal library made from these cultures, is altered in its $C$ terminal, and its message and protein are significantly expressed in the brain. GLT1b is expressed in presynaptic terminals and in dendritic shafts as well as in astrocytes in the normal mature rodent brain. The quantitative significance of this expression has yet to be determined. The existence of variant forms of GLT1 and the expression of GLT1 in neurons is likely to have important implications for the physiology and pathophysiology of glutamate transport and excitatory neurotransmission.

\section{REFERENCES}

Aoki C, Venkatesan C, Go C-G, Mong JA, Dawson TM (1994) Cellular and subcellular localization of NMDA-R1 subunit immunoreactivity in the visual cortex of adult and neonatal rats. J Neurosci 14:5202-5222.

Aoki C, Rodrigues S, Kurose H (1999) Use of electron microscopy in the detection of adrenergic receptors. In: Methods in molecular biology: adrenergic receptor protocols (Machida CA, ed), pp 535-563. Totowa, NJ: Humana.

Arriza JL, Fairman WA, Wadiche JI, Murdoch GH, Kavanaugh MP, Amara SG (1994) Functional comparisons of three glutamate transporter subtypes cloned from human motor cortex. J Neurosci 14:5559-5569.

Arriza JL, Eliasof S, Kavanaugh MP, Amara SG (1997) Excitatory amino acid transporter 5, a retinal glutamate transporter coupled to a chloride conductance. Proc Natl Acad Sci USA 94:4155-4160.

Asztely F, Erdemli G, Kullmann DM (1997) Extrasynaptic glutamate spillover in the hippocampus: dependence on temperature and the role of active glutamate uptake. Neuron 18:281-293.

Attwell D, Barbour B, Szatkowski M (1993) Nonvesicular release of neurotransmitter. Neuron 11:401-407.

Berger UV, Hediger MA (1998) Comparative analysis of glutamate transporter expression in rat brain using differential double in situ hybridization. Anat Embryol 198:13-30.

Brakeman PR, Lanahan AA, O'Brien R, Roche K, Barnes CA, Huganir RL, Worley PF (1997) Homer: a protein that selectively binds metabotropic glutamate receptors. Nature 386:284-288.

Brooks-Kayal AR, Munir M, Jin H, Robinson MB (1998) The glutamate transporter, GLT-1, is expressed in cultured hippocampal neurons. Neurochem Int 33:95-100.

Chan J, Aoki C, Pickel VM (1990) Optimization of differential immunogold-silver and peroxidase labeling with maintenance of ultrastructure in brain sections before plastic embedding. J Neurosci Methods 33:113-127.

Chaudhry FA, Lehre KP, Campagne MV, Ottersen OP, Danbolt NC, Storm-Mathisen J (1995) Glutamate transporters in glial plasma membranes: Highly differentiated localizations revealed by quantitative ultrastructural immunocytochemistry. Neuron 15:711-720.

Chen W, Hadley R, Gruber C, Irwin N, Rosenberg PA (1998) Glutamate transporter expression in rat neurons in culture. Soc Neurosci Abstr 24:2066.

Chen W, Hadley R, Gruber C, Irwin N, Rosenberg PA (1999) GLT1 is the dominant functional glutamate transporter in rat forebrain neurons in culture. Soc Neurosci Abstr 25:431.

Chen W, Aoki C, Gruber CE, Hadley RG, Wang GJ, Blitzblau R, Irwin N, Rosenberg PA (2000) Molecular cloning, functional characterization, and neuronal localization of a variant form of the glutamate transporter GLT1. Soc Neurosci Abstr 26:1443.

Coco S, Verderio C, Trotti D, Rothstein JD, Volterra A, Matteoli M (1997) Non-synaptic localization of the glutamate transporter EAAC1 in cultured hippocampal neurons. Eur J Neurosci 9:1902-1910.

Cuenod M, Bagnoli P, Beaudet A, Rustioni A, Wiklund L, Streit P (1982) Transmitter-specific retrograde labeling of neurons. In: Cytochemica methods in neuroanatomy (Palay SL, Chan-Palay V, eds), pp 17-44. New York: Alan R. Liss.

Danbolt NC (2001) Glutamate uptake. Prog Neurobiol 65:1-105.

Davis KE, Straff DJ, Weinstein EA, Bannerman PG, Correale DM, Rothstein JD, Robinson MB (1998) Multiple signaling pathways regulate cell surface expression and activity of the excitatory amino acid carrier 1 subtype of Glu transporter in C6 glioma. J Neurosci 18:2475-2485.

Divac I, Fonnum F, Storm-Mathisen J (1977) High affinity uptake of glutamate in terminals of corticostriatal axons. Nature 266:377-378.

Dong H, O'Brien RJ, Fung ET, Lanahan AA, Worley PF, Huganir RL (1997) GRIP: a synaptic PDZ domain-containing protein that interacts with AMPA receptors. Nature 386:279-284.

Dowd LA, Robinson MB (1996) Rapid stimulation of EAAC1-mediated 
$\mathrm{Na}^{+}$-dependent L-glutamate transport activity in C6 glioma cells by phorbol ester. J Neurochem 67:508-516.

Fairman WA, Vandenberg RJ, Arriza JL, Kavanaugh MP, Amara SG (1995) An excitatory amino-acid transporter with properties of a ligand-gated chloride channel. Nature 375:599-603.

Ferkany J, Coyle JT (1986) Heterogeneity of sodium-dependent excitatory amino acid uptake mechanisms in rat brain. J Neurosci Res 16:491-503.

Furuta A, Rothstein JD, Martin LJ (1997) Glutamate transporter protein subtypes are expressed differentially during rat CNS development. J Neurosci 17:8363-8375.

Garlin AB, Sinor AD, Sinor JD, Jee SH, Grinspan JB, Robinson MB (1995) Pharmacology of sodium-dependent high-affinity L- $\left[{ }^{3} \mathrm{H}\right]$ glutamate transport in glial cultures. J Neurochem 64:2572-2580.

Gluzman Y (1981) SV40-transformed simian cells support the replication of early SV40 mutants. Cell 23:175-182.

Gundersen V, Danbolt NC, Ottersen OP, Storm-Mathisen J (1993) Demonstration of glutamate/aspartate uptake activity in nerve endings by use of antibodies recognizing exogenous D-aspartate. Neuroscience 57:97-111.

Gundersen V, Shupliakov O, Brodin L, Ottersen OP, Storm-Mathisen J (1995) Quantification of excitatory amino acid uptake at intact glutamatergic synapses by immunocytochemistry of exogenous D-aspartate. J Neurosci 15:4417-4428.

He Y, Janssen WGM, Rothstein JD, Morrison JH (2000) Differential synaptic localization of the glutamate transporter EAAC1 and glutamate receptor subunit GluR2 in the rat hippocampus. J Comp Neurol 418:255-269.

Iversen LL, Storm-Mathisen J (1976) Uptake of (3H)glutamate in excitatory nerve endings in the hippocampal formation of the rat. Act Physiol Scand 96:22A-23A.

Kanai Y, Hediger MA (1992) Primary structure and functional characterization of a high-affinity glutamate transporter. Nature 360:467-471.

Kanner BI, Danbolt N, Pines G, Koepsell H, Seeberg E, Mathisen J-S (1993) Structure and function of the sodium and potassium-coupled glutamate transporter from rat brain. Biochem Soc Trans 21:59-61.

Kim JH, Huganir RL (1999) Organization and regulation of proteins at synapses. Curr Opin Cell Biol [Erratum (1999) 11:407-408] $11: 248-254$.

Koch HP, Kavanaugh MP, Esslinger CS, Zerangue N, Humphrey JM, Amara SG, Chamberlin AR, Bridges RJ (1999) Differentiation of substrate and nonsubstrate inhibitors of the high-affinity, sodiumdependent glutamate transporters. Mol Pharmacol 56:1095-1104.

Lehre KP, Danbolt NC (1998) The number of glutamate transporter subtype molecules at glutamatergic synapses: chemical and stereological quantification in young adult rat brain. J Neurosci 18:8751-8757.

Lehre KP, Levy LM, Ottersen OP, Storm-Mathisen J, Danbolt NC (1995) Differential expression of two glial glutamate transporters in the rat brain: quantitative and immunocytochemical observations. J Neurosci 15:1835-1853.

Lin CLG, Bristol LA, Jin L, Dykes-Hoberg M, Crawford T, Clawson L, Rothstein JD (1998) Aberrant RNA processing in a neurodegenerative disease: the cause for absent EAAT2 a glutamate transporter, in amyotrophic lateral sclerosis. Neuron 20:589-602.

Lipton SA, Rosenberg PA (1994) Excitatory amino acids as a final common pathway for neurologic disorders. N Engl J Med 330:613-622.

Mangano RM, Schwarcz R (1983) Chronic infusion of endogenous excitatory amino Acids into rat stratum and hippocampus. Brain Res 10:47-51.

Matsubara A, Laake H, Davanger S, Usami S, Ottersen OP (1996) Organization of AMPA receptor subunits at a glutamate synapse: a quantitative immunogold analysis of hair cell synapses in the rat organ of Corti. J Neurosci 16:4457-4467.

McCarthy KD, de Vellis J (1980) Preparation of separate astroglial and oligodendroglial cell cultures from rat cerebral tissue. J Cell Biol 85:890-902.

Meldrum B, Garthwaite J (1990) Excitatory amino acid neurotoxicity and neurodegenerative disease. Trends Pharmacol Sci 11:379-387.

Mennerick S, Dhond RP, Benz A, Xu WY, Rothstein JD, Danbolt NC, Isenberg KE, Zorumski CF (1998) Neuronal expression of the glutamate transporter GLT-1 in hippocampal microcultures. J Neurosci 18:4490-4499.

Meyer T, Ludolph AC, Morkel M, Hagemeier C, Speer A (1997) Genomic organization of the human excitatory amino acid transporter gene GLT-1. NeuroReport 8:775-777.

Morris HR, Perez-Tur J, Janssen JC, Brown J, Lees AJ, Wood NW, Hardy J, Hutton M, Rossor MN (1999) Mutation in the tau exon 10 splice site region in familial frontotemporal dementia. Ann Neurol 45:270-271.

Nicholls D, Attwell D (1990) The release and uptake of excitatory amino acids. Trends Pharmacol Sci 11:462-468.

Niethammer M, Kim E, Sheng M (1996) Interaction between the C terminus of NMDA receptor subunits and multiple members of the PSD-95 family of membrane-associated guanylate kinases. J Neurosci 16:2157-2163.
Phend KD, Rustioni A, Weinberg RJ (1995) An osmium-free method of Epon embedment that preserves both ultrastructure and antigenicity for post-embedding immunocytochemistry. J Histochem Cytochem 43:283-292.

Pines G, Danbolt NC, Bjoras M, Zhang Y, Bendahan A, Eide L, Koepsell J, Storm-Mathisen J, Seeberg E, Kanner BI (1992) Cloning and expression of a rat brain L-glutamate transporter. Nature 360:464-467.

Poorkaj P, Bird TD, Wijsman E, Nemens E, Garruto RM, Anderson L, Andreadis A, Wiederholt WC, Raskind M, Schellenberg GD (1998) Tau is a candidate gene for chromosome 17 frontotemporal dementia. Ann Neurol [Erratum (1998) 44:428] 43:815-825.

Robinson MB, Sinor JD, Dowd LA, Kerwin Jr JF (1993) Subtypes of sodium-dependent high-affinity $\mathrm{L}-\left[{ }^{3} \mathrm{H}\right]$ glutamate transport activity: Pharmacologic specificity and regulation by sodium and potassium. J Neurochem 60:167-179.

Roginski RS (1996) A model for the expression of different glutamate transporter proteins from a rat astrocyte-type glutamate transporter gene. In: Neurodegenerative diseases: molecular and cellular mechanisms and therapeutic advances (Fiskum G, ed), pp 29-32. New York: Plenum.

Rosenberg PA (1991) Accumulation of extracellular glutamate and neuronal death in astrocyte-poor cortical cultures exposed to glutamine. Glia 4:91-100.

Rosenberg PA, Aizenman E (1989) Hundred-fold increase in neuronal vulnerability to glutamate toxicity in astrocyte-poor cultures of rat cerebral cortex. Neurosci Lett 103:162-168.

Rosenberg PA, Amin S, Leitner M (1992) Glutamate uptake disguises neurotoxic potency of glutamate agonists in cerebral cortex in dissociated cell culture. J Neurosci 12:56-61.

Rothstein JD, Martin L, Levey AI, Dykes-Hoberg M, Jin L, Wu D, Nash N, Kuncl RW (1994) Localization of neuronal and glial glutamate transporters. Neuron 13:713-725.

Rothstein JD, Dykes-Hoberg M, Pardo CA, Bristol LA, Jin L, Kuncl RW, Kanai Y, Hediger MA, Wang YF, Schielke JP, Welty DF (1996) Knockout of glutamate transporters reveals a major role for astroglial transport in excitotoxicity and clearance of glutamate. Neuron 16:675-686.

Rusakov DA, Kullmann DM (1998) Extrasynaptic glutamate diffusion in the hippocampus: Ultrastructural constraints, uptake, and receptor activation. J Neurosci 18:3158-3170.

Schlag BD, Vondrasek JR, Munir M, Kalandadze A, Zelenaia OA, Rothstein JD, Robinson MB (1998) Regulation of the glial $\mathrm{Na}^{+}$ dependent glutamate transporters by cyclic AMP analogs and neurons. Mol Pharmacol 53:355-369.

Seki Y, Feustel PJ, Keller Jr RW, Tranmer BI, Kimelberg HK (1999) Inhibition of ischemia-induced glutamate release in rat striatum by dihydrokinate and an anion channel blocker. Stroke 30:433-440.

Shashidharan P, Huntley GW, Murray JM, Buku A, Moran T, Walsh MJ, Morrison JH, Plaitakis A (1997) Immunohistochemical localization of the neuron-specific glutamate transporter EAAC1 (EAAT3) in rat brain and spinal cord revealed by a novel monoclonal antibody. Brain Res 773:139-148.

Sheng M, Pak DT (1999) Glutamate receptor anchoring proteins and the molecular organization of excitatory synapses. Ann NY Acad Sci 868:483-493.

Sheng M, Sala C (2001) PDZ domains, the organization of supramolecular complexes Annu Rev Neurosci 24:1-29.

Storck T, Schulte S, Hofmann K, Stoffel W (1992) Structure, expression, and functional analysis of a Na${ }^{+}$-dependent glutamate/aspartate transporter from rat brain. Proc Natl Acad Sci USA 89:10955-10959.

Storm-Mathisen J (1977) Glutamic acid and excitatory nerve endings: reduction of glutamic acid uptake after axotomy. Brain Res $120: 379-386$.

Storm-Mathisen J, Iversen LL (1979) Uptake of [3H] glutamaic acid in excitatory nerve endings: light and electronmicroscopic observations in the hippocampal formation of the rat. Neuroscience 4:1237-1253.

Sutherland ML, Delaney TA, Noebels JL (1996) Glutamate transporter mRNA expression in proliferative zones of the developing and adult murine CNS. J Neurosci 16:2191-2207.

Swanson RA, Miller JW, Rothstein JD, Farrell K, Stein BA, Longuemare MC (1997) Neuronal regulation of glutamate transporter subtype expression in astrocytes. J Neurosci 17:932-940.

Szatkowski M, Barbour B, Attwell D (1990) Non-vesicular release of glutamate from glial cells by reversed electrogenic glutamate uptake. Nature 348:443-446.

Tanaka K, Watase K, Manabe T, Yamada K, Watanabe M, Takahashi K, Iwama H, Nishikawa T, Ichihara N, Hori S, Takimoto M, Wada K (1997) Epilepsy and exacerbation of brain injury in mice lacking the glutamate transporter GLT-1. Science 276:1699-1702.

Torp R, Danbolt NC, Babaie E, Bjoras M, Storm-Mathisen J, Ottersen OP (1995) Differential expression of two glial glutamate transporters in the rat brain: in situ hybridization study. Eur J Neurosci 6:936-942.

Utsunomiya-Tate N, Endou H, Kanai Y (1997) Tissue specific variants of glutamate transporter GLT-1. FEBS Lett 416:312-316.

Varani L, Hasegawa M, Spillantini MG, Smith MJ, Murrell JR, Ghetti B, 
Klug A, Goedert M, Varani G (1999) Structure of tau exon 10 splicing regulatory element RNA and destabilization by mutations of frontotemporal dementia and parkinsonism linked to chromosome 17. Proc Natl Acad Sci USA 96:8229-8234.

Velaz-Faircloth M, McGraw TS, Malandro MS, Fremeau Jr RT, Kilberg MS, Anderson KJ (1996) Characterization and distribution of the neuronal glutamate transporter EAAC1 in rat brain. Am J Physiol Cell Physiol 270:C67-C75.

Ventura R, Harris KM (1999) Three-dimensional relationships between hippocampal synapses and astrocytes. J Neurosci 19:6897-6906.

Veznedaroglu E, Milner TA (1992) Elimination of artifactual labeling of hippocampal mossy fibers seen following pre-embedding immunogold- silver technique by pretreatment with zinc chelator. Microsc Res Tech 23:100-101.

Wang GJ, Chung HJ, Schnuer J, Pratt K, Zable AC, Kavanaugh MP Rosenberg PA (1998a) High affinity glutamate transport in rat cortical neurons in culture. Mol Pharmacol 53:88-96.

Wang GJ, Chung HJ, Schnuer J, Lea E, Robinson MB, Potthoff WK, Aizenman E, Rosenberg PA (1998b) Dihydrokainate-sensitive neuronal glutamate transport is required for protection of rat cortical neurons in culture against synaptically released glutamate. Eur J Neurosci 10:2523-2531.

Ziff EB (1997) Enlightening the postsynaptic density. Neuron 19:11631174. 